Kinestetik : Jurnal Ilmiah Pendidikan Jasmani 5 (3) (2021)
Kinestetik : Jurnal Ilmiah Pendidikan Jasmani
https://ejournal.unib.ac.id/index.php/kinestetik/index
DOI : 10.33369/jk.v5i3.18151

\title{
THE ROLE OF PROJECT-BASED LEARNING (PJBL) MODELS IN IMPROVING THE ABILITY TO ORGANIZE WRESTLING SPORTS COMPETITIONS FOR PHYSICAL EDUCATION STUDENTS FKIP TANJUNGPURA UNIVERSITY
} \section{Tanjungpura, Indonesia

\begin{tabular}{l} 
Article Info \\
\hline Article History : \\
Received : September 2021 \\
Revised : September 2021 \\
Accepted : September 2021 \\
Available online : September \\
2021
\end{tabular}

Muhammad Fachrurrozi Bafadal $^{1 *}$, Mimi Haetami2

1,2Physical Education Program,Teaching Training and Education Faculty, Universitas

Keywords:

Project Based Learning, ability, Physical Education

\begin{abstract}
Improving the ability to organize sports competitions in wrestling courses for physical education students in semester 5 of 2021 by using the Project-based learning (PjBL) model is the goal of this research. This research method is Class Action (CAR) there are 2 cycles, each cycle 2 meetings are consisting of planning, action, observation, and reflection. The sample of this study amounted to 12 students and used purposive sampling. The results of this study indicate, during the pre-cycle to cycle II, there was an increase in the ability to organize sports competitions. In the pre-cycle, it has not shown the ability to organize sports matches by 461 points with a percentage of $38.41 \%$ and is included in the very poor category, an increase in the ability to organize sports matches in the first cycle is 749 points with a percentage of $62.41 \%$ moving up to the moderate category and continues increased in the second cycle by 1001 points with a percentage of $83.41 \%$ and continued to climb into the Good category. The conclusion in this study is that the ability to organize wrestling competitions for physical education students, FKIP Tanjungpura University can be improved through the Project-Based Learning (PJBL) learning model as seen from the percentage of cycle II of $83.41 \%$ with the Good category, this means that physical education.
\end{abstract}

\begin{tabular}{llr}
\hline Corresponding address & : Jalan Karangan Blok B. 7 komplek UNTAN & ISSN 2685-6514 (Online) \\
*Corresponding email & : mfachrurrozibafadal@fkip.untan.ac.id & ISSN 2477-331X (Print)
\end{tabular}




\section{INTRODUCTION}

The acceleration of improving the quality of higher education must be carried out immediately, to improve the quality of the higher education institution. Quality improvement can be obtained by changing the strategy, namely improving the quality of people, organizational structures, and processes and applying technology in the process. To improve the quality of human resources consisting of lecturers and students, various learning models are needed and improve 21stcentury capabilities. Several learning models can be applied in educational units, but learning that directly applies material by actualizing knowledge into activities that are real, fun, and easier for students to understand, there are only a few models. One alternative model that can improve 21st-century capabilities is the project-based learning model (PJBL).(Dewi, 2015).

PJBL is a learning model that involves students in a project based on a problem and in the end students can produce real work. In line with what is described (Ardianti et al., 2017), that Project-based learning ( $\mathrm{PjBL})$ is a learning model with a special characteristic of designing and carrying out a project in it to produce a product. The PJBL learning model is needed at the tertiary level, innovative and creative learning strategies or lectures need to be developed. Not only giving assignments without any assessment, but learning needs independence, thinking skills, and the opportunity to actualize the theory that has been obtained in the study room. In the physical education study program, the Faculty of Education and Education at Tanjungpura University has implemented several learning models such as cooperative models (Dosinaen et al., 2020; Pratama et al., 2019; Turrahma et al., 2019), direct learning (Irvan et al., 2015), and other learning models except for PJBL.

Learning for physical education students at the Tanjungpura University FKIP, especially the wrestling course, is very monotonous and seems boring. Learning activities start with giving an introduction to learning such as understanding the history of wrestling, introduction, and practice of basic wrestling techniques, and the rules of wrestling matches. Considered incapable of achieving learning goals or wrestling lectures as a whole. And no model has ever been applied in summarizing the overall achievements of wrestling lectures. It is deemed necessary to apply the PJBL model that can apply the objectives of the wrestling lectures. By giving a project to students related to simply organizing wrestling matches, which means students organize competitions in the smallest scope, namely between classes taking wrestling courses. Following the opinion (Hanif, 2016), that the organization of the match is also called the implementing committee, which consists of individuals who are skilled and tasked with carrying out the tasks they carry out so that all activities from planning the things needed to the stage of completing the 
implementation can be successful. without significant obstacles. Based on the results of observations made by the researchers on physical education students at Tanjungpura University FKIP semester 5 in 2021 , there were $25 \%$ of the 45 students had been and were directly involved in organizing sports committees, both at school and in the student's neighborhood. With the lack of knowledge and experience of students who organize sports competitions, students need to integrate theories in learning, practice, and problems that will arise in the process and will improve the ability to organize sports competitions that students will get later after entering the world of work and requires students to adapt to the challenges of completing a project.

To organize a sports competition, a matching design is needed so that the smooth implementation of achieving the expected goals. There are several elements needed to design a sports competition, namely legality, the purpose of the match, designing the organizational structure of the match, determining the composition of the implementing committee, determining the right time and place, determining the scope and number of participants, making a schedule of activities (Hanif, 2016). By implementing project-based lectures or organizing sports competition activities in this wrestling course, it is hoped that students can actualize the theories that have been obtained in wrestling material and students gain experience in applying the rules of wrestling matches and the refereeing system in wrestling. With the learning characteristics of physical education students whose learning is almost $60 \%$ using practical learning (Kardani, 2019), it is necessary to use the Project-based Learning (PJBL) model as the right solution in achieving the goals of wrestling lectures and there is no doubt that physical education students can complete this project.

\section{METHODS}

Class action research, the authors chose as the method in this research, which is implemented in wrestling courses. In classroom action research, the writer chooses the Spiral Kemmis and Taggart models, which have a minimum of 2 cycles, each cycle consisting of planning, action, observation, and reflection. And this research focuses on improving the ability of physical education students of FKIP Tanjungpura University in organizing wrestling matches through the PJBL learning model.

\section{Participants}

The population in this study were physical education students at the Tanjungpura University FKIP Semester 5 in 2021, which were 45 students.

\section{Sampling Procedures}

The sample used in this study used purposive sampling. According to (Guarte \& Barrios, 2007), purposive sampling is described as a random selection of sampling units in the population segment with the most information about the desired characteristics. This sample is used to determine the number of people studied 
following special provisions or purposes. The purpose of selecting the sample in this study, students who independently became the organizing committee for wrestling subjects were only 12 students.

\section{Materials and Apparatus}

The tool or test that the researcher uses in this research opportunity is to use a questionnaire on the ability to organize sports competitions and observations.

\section{Procedures}

This research procedure uses Classroom Action Research (CAR) which aims to solve existing learning problems. In this study, the authors collaborated with lecturers of the physical education study program, FKIP, Tanjungpura University. The implementation of this research has 3 stages consisting of problem formulation, improvement consisting of planning, action and observation, and reflection. And this research uses 2 cycles and each cycle has 2 meetings.

\section{Design or Data Analysis}

The data analysis of this research is using quantitative descriptive analysis.

\section{RESULTS}

Based on the results of the research that has been carried out and based on the results of pre-cycle observations, cycle I and cycle II showed good progress in improving the ability to organize wrestling competitions. Below is the average increase for each cycle.
Table 1. Average Observation Results The ability of students to organize Wrestling sports competitions.

\begin{tabular}{llll}
\hline \multicolumn{1}{c}{ Variable } & \multicolumn{3}{c}{ Cycle PTK } \\
\cline { 2 - 4 } & $\begin{array}{l}\text { Pre } \\
\text { Cycle }\end{array}$ & Cycle I & Cycle II \\
\hline Ability to & 461 & 749 & 1001 \\
organize & $(38,41 \%$ & $(62,41 \%$ & $(83,41 \%$ \\
sports & ) & ) & ) \\
competition & & & \\
s & & & \\
\hline
\end{tabular}

Based on the table above, during the pre-cycle to cycle II, there was an increase in the ability to organize sports competitions. In the pre-cycle, it has not shown the ability to organize sports competitions by 461 points with a percentage of $38.41 \%$ and is included in the very poor category, an increase in the ability to organize sports matches in the first cycle of 749 points with a percentage of $62.41 \%$ moves up to the moderate category and continues increased in the second cycle by 1001 points with a percentage of $83.41 \%$ and continued to increase into the Good category. The following is a diagram of the percentage increase in the ability to organize sports competitions during wrestling lectures by applying the PJBL model:

$$
\begin{aligned}
& \text { Ability to organize sports } \\
& \text { competitions. Ability to organize sports } \\
& \text { competitions }
\end{aligned}
$$

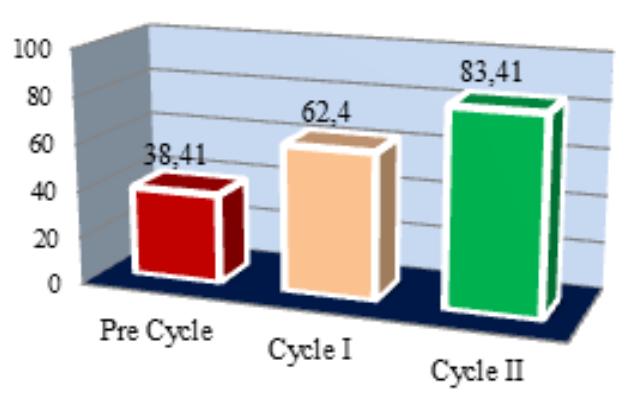


the results of observations of the average ability to organize sports competitions for physical education students from FKIP Tanjungpura University can be described below:

Table 2. Observations on the ability to organize sports competitions in cycles I and II.

\begin{tabular}{|c|c|c|c|c|}
\hline & \multirow[t]{2}{*}{$\begin{array}{c}\text { Elements of Designing a } \\
\text { match }\end{array}$} & \multicolumn{2}{|c|}{$\begin{array}{c}\text { Percentage } \\
(\%)\end{array}$} & \multirow{2}{*}{$\begin{array}{l}\text { Informat } \\
\text { ion }\end{array}$} \\
\hline & & $\begin{array}{c}\text { Cycle } \\
\text { I }\end{array}$ & $\begin{array}{c}\text { Cycle } \\
\text { II }\end{array}$ & \\
\hline 1 & $\begin{array}{l}\text { Students can get } \\
\text { legality/legitimacy from } \\
\text { wrestling organizations in } \\
\text { organizing matches }\end{array}$ & 72 & 90 & Increase \\
\hline 2 & $\begin{array}{l}\text { Students have a match } \\
\text { goal to be achieved }\end{array}$ & 70 & 80 & Increase \\
\hline 3 & $\begin{array}{l}\text { Students can design a } \\
\text { competitive organizational } \\
\text { structure that describes the } \\
\text { duties and responsibilities } \\
\text { in each section. }\end{array}$ & 65 & 85 & Increase \\
\hline 4 & $\begin{array}{l}\text { Students can determine the } \\
\text { composition of the } \\
\text { implementing committee } \\
\text { according to the student's } \\
\text { abilities }\end{array}$ & 61 & 82 & Increase \\
\hline 5 & $\begin{array}{l}\text { Students can determine the } \\
\text { time of the competition }\end{array}$ & 62 & 88 & Increase \\
\hline 6 & $\begin{array}{l}\text { Students can determine } \\
\text { where the competition will } \\
\text { be held that does not } \\
\text { interfere with the comfort } \\
\text { of the participants }\end{array}$ & 56 & 78 & Increase \\
\hline 7 & $\begin{array}{l}\text { Students can determine the } \\
\text { scope or size of the } \\
\text { participant's participation. }\end{array}$ & 64 & 82 & Increase \\
\hline 8 & $\begin{array}{l}\text { Students can estimate the } \\
\text { number of participants } \\
\text { who take part in the } \\
\text { competition }\end{array}$ & 65 & 81 & Increase \\
\hline 9 & $\begin{array}{l}\text { Students can schedule } \\
\text { Activities }\end{array}$ & 57 & 86 & Increase \\
\hline 10 & $\begin{array}{l}\text { At the preparation stage, } \\
\text { students can carry out: } \\
\text { initial meeting activities, } \\
\text { equipment preparation, } \\
\text { field preparation, form } \\
\text { creation, sending } \\
\text { notification invitations, } \\
\text { registration, technical } \\
\text { meetings (technical } \\
\text { meetings) }\end{array}$ & 59 & 83 & Increase \\
\hline 11 & $\begin{array}{l}\text { At the implementation } \\
\text { stage, students can do: } \\
\text { opening, competition, } \\
\text { closing }\end{array}$ & 58 & 87 & Increase \\
\hline 12 & $\begin{array}{l}\text { In the final stage, students } \\
\text { can carry out: Reports and } \\
\text { accountability }\end{array}$ & 60 & 79 & Increase \\
\hline
\end{tabular}

\section{DISCUSSION}

The results of the research on the ability to organize wrestling matches in 12 physical education students of FKIP Tanjungpura University in the wrestling course showed that an increase occurred from pre-cycle to cycle I and an increase occurred again in cycle II. This confirms that the student's ability to organize a sports competition is in a good category because they have carried out $83,41 \%$ of the 20 statements that have been observed by physical education lecturers, FKIP Tanjungpura University. Based on table 2 . In point 1 , it can be seen that there was an increase in cycle I by $72 \%$ to cycle II by $90 \%$, indicating that students can understand that an activity must have the basis or legality of the management of the sports branch that houses it, especially the management of the wrestling branch in the city. Pontianak to get a letter of recommendation for activities or an official letter of assignment from the management of the sports branch and be able to expedite the matches in these activities (Nindyawan \& Mulyono, 2021).

In the second point, there was a significant increase that from $65 \%$ in the first cycle it crawled up to $80 \%$ in the second cycle. Determining the purpose of organizing the match has the same vision as the Pontianak city wrestling administrator who develops coaching and becomes an evaluation material for the results of wrestling training.

At points 3 to 12 which consist of designing the organizational structure of 
the match, determining the composition of the implementing committee, determining the time and place, determining the scope and number of participants, making a schedule of activities (Tapo \& Bile, 2020) there is an increase in the percentage between $21 \%$ which means that students understand and can carry out their functions and duties when they are members of the committee. So that in carrying out the match system smoothly, precisely according to the regulations, so that the charts do not overlap and are timely in completing the match (Sakti et al., 2020).

Giving responsibility to students by assigning a project will increase students' learning motivation (Yani, 2018) and student learning outcomes (Wahyudi et al., 2018). By applying the PJBL model, it can strengthen and practice the main tasks of the committee and also improve ways of communicating and thinking creatively (Nugroho et al., 2019) because students are required to be active in coordinating with related parties, both lecturers, sports administrators, and event participants and the organizing committee.

\section{CONCLUSION}

The ability to organize wrestling competitions for physical education students, FKIP Tanjungpura University can be improved through the ProjectBased Learning (PJBL) learning model as seen from the percentage of cycle II of $83.41 \%$, this means that physical education students have implemented and understood and can carry out the functions and the duties of each member of the organizing committee for sports competitions in the Good category. So that the implementation is completed on time, according to the rules and the game system runs smoothly.

\section{ACKNOWLEDGEMENT}

The author thanks his beloved wife, Fitriana Puspa Hidasari, and their two daughters, namely Azzahra Afsheena Bafadal and Berlian Andita Bafadal who have helped and supported the completion of this article.

\section{REFERENCES}

Ardianti, S. D., Pratiwi, I. A., \& Kanzunnudin, M. (2017). Implementasi Project Based Learning (PJBL) Berpendekatan Science Edutainment Terhadap Kreativitas Peserta Didik. Refleksi Edukatika: Jurnal Ilmiah Kependidikan, $\quad 7(2)$. https://jurnal.umk.ac.id/index.php/RE/a rticle/view/1225

Dewi, F. (2015). Proyek Buku Digital: Upaya Peningkatan Keterampilan Abad 21 Calon Guru Sekolah Dasar Melalui Model Pembelajaran Berbasis Proyek. Metodik Didaktik: Jurnal Pendidikan $K e-S D-A n$, 9(2). https://ejournal.upi.edu/index.php/Meto dikDidaktik/article/view/3248

Dosinaen, M. A., Simanjuntak, V. G., \& Hidasari, F. P. (2020). Meningkatkan Hasil Belajar Menggiring Dalam Sepak Bola melalui Cooperative Learning Type Tgt. Jurnal Pendidikan Dan Pembelajaran Khatulistiwa, 9(6). https://jurnal.untan.ac.id/index.php/jpdp b/article/view/41012

Guarte, J. M., \& Barrios, E. B. (2007). Estimation Under Purposive Sampling. Https://Doi.Org/10.1080/03610910600 591610, 35(2), 277-284. 
https://doi.org/10.1080/0361091060059 1610

Hanif, A. S. (2016). Manajemen Penyelenggaraan Pertandingan Sepak Takraw (1st ed., Vol. 1). Rajawali Pers. https://books.google.co.id/books?hl=id $\& \mathrm{lr}=\& \mathrm{id}=\mathrm{bNQaEAAAQBAJ} \& \mathrm{i}=\mathrm{fnd} \&$ $\mathrm{pg}=\mathrm{PA} 42 \& \mathrm{dq}=$ manajemen+pertandinga n+olahraga\&ots $=7 \mathrm{wcFmwRpPG \& sig}=$ e9ATtty9XVWFZ-

tZPhnYdsZ0aew\&redir_esc=y\#v=onep age $\& \mathrm{q}=$ manajemen pertandingan olahraga $\& \mathrm{f}=$ false

Irvan, Haetami, M., \& Fitriana Puspa, H. (2015). Perbandingan Model Pembelajaran PBL dan DI Terhadap Hasil Belajar Servis Atas Bola Voli Pada Peserta Didik Di Sma. Jurnal Pendidikan Dan Pembelajaran Khatulistiwa.

Kardani, G. (2019). Analisis Pengembangan Kurikulum PJKR S1 Universitas Galuh. Jurnal Wahana Pendidikan, 4(1), 2633. https://doi.org/10.25157/WA.V4I1.384

Nindyawan, S. T., \& Mulyono, A. (2021). Barriers to the Implementation of Table Official at the Srikandi CUP. Indonesian Journal for Physical Education and Sport, 2(1), 358 â€" 364-358 â€“" 364. https://doi.org/10.15294/INAPES.V2I1. 45519

Nugroho, A. T., Jalmo, T., \& Surbakti, A. (2019). Pengaruh Model Project Based Learning (PjBL) Terhadap Kemampuan Komunikasi dan Berpikir Kreatif. Jurnal Bioterdidik: Wahana Ekspresi Ilmiah, $\quad 7(3), \quad 50-58$. http://jurnal.fkip.unila.ac.id/index.php/J BT/article/view/17428

Pratama, G., Hidasari, F. P., \& Triansyah, A. (2019). Penerapan Model Cooperative Learning Tipe Student Teams Achievement Division Terhadap Hasil Belajar Passing Permainan Sepak Bola. Jurnal Pendidikan Dan Pembelajaran Khatulistiwa, $\quad 8(3)$. https://jurnal.untan.ac.id/index.php/jpdp b/article/view/31597

Sakti, N. W. P., S, E. W., \& Sukarman, S. (2020). Sosialisasi Peningkatan Pengetahuan Remaja Karang Taruna
Desa Tamansari Kecamatan Gunungsari Terhadap Organisasi Dan Sistem Pertandingan Olahraga. Abdi Masyarakat, 2(2). https://doi.org/10.36312/ABDI.V2I2.16 43

Tapo, Y. B. O., \& Bile, R. L. (2020). Pelatihan Manajemen Penyelenggaraan Turnamen Bola Voli Antar Pelajar Sma/Smk Sekabupaten Ngada-Nagekeo Bagi Mahasiswa Pjkr Stkip Citra Bakti. Jurnal Abdimas Ilmiah Citra Bakti, 1(1), 29-38. https://doi.org/10.38048/JAILCB.V1I1. 82

Turrahma, A., Haetami, M., \& Hidasari, F. P. (2019). Pengaruh Model Pembelajaran Group Investigation Terhadap Keterampilan Handspring. Jurnal Pendidikan Dan Pembelajaran Khatulistiwa, $\quad 8(8)$. https://jurnal.untan.ac.id/index.php/jpdp b/article/view/34983

Wahyudi, P. D. A., Astra, I. K. B., \& Suwiwa, I. G. (2018). *Pengaruh Model Pembelajaran Project Based Learning (PJBL) Berbantuan Media Kartu Bergambar Terhadap Hasil Belajar Teknik Tangkisan Pencak Silat. Jurnal Pendidikan Jasmani, Olahraga Dan Kesehatan Undiksha, 5(2). https://ejournal.undiksha.ac.id/index.ph p/JJP/article/view/14793

Yani, A. (2018). Pengaruh Model Pembelajaran Project Based Learning Terhadap Peningkatan Motivasi Belajar Siswa Di Sekolah Menengah Kejuruan. Jurnal Kependidikan Jasmani Dan Olahraga, 2(1), 10-15. https://ejournal.stkipnu.ac.id/public_ht $\mathrm{ml} /$ ejournal/index.php/jkjo/article/view/ 27 